\title{
Mortality among United Kingdom servicemen who served abroad in the 1950s and 1960s
}

\author{
S C Darby, C R Muirhead, R Doll, G M Kendall, B Thakrar
}

\section{Abstract}

The Registrar General's decennial supplements on occupational mortality provide only limited information on mortality in the armed forces in the United Kingdom. Mortality has therefore been studied among a group of 30619 United Kingdom servicemen who served abroad in tropical or desert areas in the 1950 s and $1960 \mathrm{~s}$, and who remained in the services for a total of at least five years.

Mortality from all causes of death, all neoplasms, and all other known non-violent causes was lower than that expected from rates for all men in England and Wales, whereas mortality from accidents and violence was raised. These differences remained after adjustment for social class, affected both officers and other ranks, and had not disappeared even after the men had been followed up for at least 20 years.

When mortality from 20 specific cancers and 10 other disease groups was examined there were significant excesses for cancers of the oesophagus (standardised mortality ratio $(S M R)=146 ; \quad p=0.03)$ and prostate $(S M R=156 ; p=0.03)$, and significant deficits for cancers of the lung (SMR = 73; $p<0.001)$, stomach $(S M R=66 ; p=0.002)$, bladder (SMR $=53 ; p=0.02)$, other specified neoplasms $(S M R=48 ; p=0.001)$, coronary heart disease $(S M R=76 ; p<0.001)$, bronchitis, emphysema, and chronic obstructive lung disease $(S M R=42 ; p<0.001)$, and for five further groups of diseases unrelated to smoking or alcohol. Examination of mortality in each of the three services separately identified two specific hazards in the Royal Navy;

ICRF Cancer Epidemiology Unit, University of Oxford, Gibson Building, Radcliffe Infirmary, Oxford OX2 6HE

S C Darby, R Doll, B Thakrar

National Radiological Protection Board, Chilton, Didcot, Oxfordshire OX11 0RQ

C R Muirhead, G M Kendall seven deaths from mesothelioma occurred compared with less than 2.06 expected $(p<0.005)$, and there was also an excess of neoplasms and of other diseases associated with alcohol (SMRs of 181 and 229; $p=0.002$ and $<0.001$ ). Mortality from smoking related diseases other than those associated with alcohol was low in all three services, particularly among officers.

Numerous studies have demonstrated the influence of lifestyle and occupation upon subsequent mortality and disease. Among the most notable of these are the Registrar General's decennial supplements on occupational mortality, which relate occupation as reported on death certificates in the years around national censuses to the number employed in each occupation as estimated in the census. ${ }^{1-4}$ For some occupations, however, and especially for men serving in the armed forces, these reports can provide only limited information. This is mainly because men in the services retire young, while mortality from most diseases is still low, so that relatively few such deaths occur to men currently enlisted in the services. The use of service ranks after retirement also gives rise to a tendency for service in the armed forces to be reported on the death certificate even when it was not the person's last occupation. Further difficulties arise in the estimation of the appropriate population, as men serving outside the United Kingdom at the time of the census will not have been counted unless they have been invalided home for treatment, and the wide fluctuations from year to year in the numbers of men serving tend to make the numbers reported in the census irrelevant to the numbers of death certificates arising in the surrounding years. We have therefore used data from a follow up study of servicemen who took part in the United Kingdom atmospheric nuclear weapon tests and experimental programmes in Australia and the Pacific Ocean during the 1950s and 1960s and of a control group of men who served abroad in tropical or desert areas at the time of the tests without participating in them ${ }^{5-7}$ to examine the effect of service on subsequent 
Table 1 Numbers of men in each of the three services who served five or more years by rank and year of enlistment

\begin{tabular}{|c|c|c|c|c|c|c|}
\hline \multirow{2}{*}{$\begin{array}{l}\text { Year of } \\
\text { enlistment }\end{array}$} & \multicolumn{2}{|l|}{$R N$} & \multicolumn{2}{|l|}{ Army } & \multicolumn{2}{|l|}{$R A F$} \\
\hline & Officers & Other ranks & Officers & Other ranks & Officers & Other ranks \\
\hline Before 1920 & 10 & 0 & 0 & 0 & 0 & 0 \\
\hline $1920-4$ & 10 & 6 & 7 & 4 & 34 & 5 \\
\hline $1925-9$ & 49 & 49 & 38 & 10 & 141 & 59 \\
\hline $1930-4$ & 96 & 218 & 87 & 32 & 185 & 117 \\
\hline $1935-9$ & 217 & 1020 & 227 & 241 & 692 & 1089 \\
\hline $1940-4$ & 245 & 887 & 212 & 324 & 1003 & 746 \\
\hline $1945-9$ & 178 & 3178 & 251 & 604 & 380 & 1295 \\
\hline $1950-4$ & 155 & 4762 & 172 & 1128 & 702 & 2711 \\
\hline 1955-9 & 38 & 1789 & 35 & 1516 & 166 & 2789 \\
\hline $1960-4$ & 0 & 32 & 4 & 357 & 34 & 259 \\
\hline 1965-9 & 0 & 0 & 0 & 15 & 0 & 9 \\
\hline Total & $998^{\star}$ & $11941 \dagger$ & 1033 & 4231 & 3337 & 9079 \\
\hline
\end{tabular}

*Includes 21 Royal Marine and 3 Royal Naval Volunteer Reserve officers.

†Includes 707 Rayal Marine other ranks and 38 Navy, Army, and Air Force Institute (NAAFI) staff.

mortality. This is justifiable as our previous studies have shown that the inclusion of men who had participated in the tests would have had no detectable effect on the results, except possibly in relation to mortality from leukaemia and multiple myeloma.

Only men who were fit, both physically and mentally, will have been accepted for enlistment, and a further selection will subsequently have taken place for service overseas. Thus the healthy worker effect, whereby employed populations are commonly seen to have lower mortality than would be expected by comparison with the corresponding age, sex, and calendar period specific national rates, would be expected to be especially strong for men in the services. We have therefore relied heavily in our analyses on comparison between the different services and ranks, as these selection criteria can be expected to have operated in a similar way for the different groups. We have restricted our analyses to men who served for at least five years, partly to eliminate any men on National Service for whom selection effects may have operated in a different way, and partly as the long term effects of a service lifestyle should be greater than in men who served for only a brief period.

\section{Study population and methods}

The method of identification of test participants and controls from Ministry of Defence records has been described previously. ${ }^{5-7}$ All 30619 servicemen (both test participants and controls) who were included in our previous study and who served for a total of at least five years are included in the present study. Forty two per cent were in the Royal Navy (RN), $17 \%$ in the Army, and $41 \%$ were in the Royal Air Force (RAF) (see table 1). Overall $18 \%$ of the men were officers, but the proportion varied by service with officers accounting for $27 \%$ in the RAF, $20 \%$ in the Army, and $8 \%$ in the RN. Just over $30 \%$ of the men enlisted in the services in the period 1950-4, about $20 \%$ in each of the periods $1945-9$ and 1955-9, and about $25 \%$ in the period before 1945 .

Follow up information to 1 January 1984 was obtained primarily from the National Health Service Central Registers and supplemented by information from Health Departments in Northern Ireland, the Isle of Man, and Jersey, and from the Department of Social Security as described in our previous reports. ${ }^{5-7}$ Deaths were coded to the ninth revision of the International Classification of Diseases (ICD).

For the present analysis person-years at risk were computed by entering men into the study five years after their enlistment in the services or on their date of entry to the main study if this occurred more than five years after enlistment. Men were removed from the study on their date of death or emigration, on their 85th birthday, or on 1 January 1984, whichever came first. Person-years were calculated separately in each calendar year and each five year age group. For each cause of death of interest the number of deaths expected was calculated by multiplying the personyears at risk by the corresponding age and calendar year specific mortality for England and Wales, obtained from computer tapes supplied by the Office of Population Censuses and Surveys. The ICD codes corresponding to the disease categories used in the present analysis are cited in our earlier report. ${ }^{6}$ For calculating the numbers of deaths expected to have a mention of mesothelioma on the death certificate, the numbers of such deaths occurring in men in Britain in ten year age groups in single calendar years from 1968 to 1983 were kindly made available by Dr RD Jones of the Health and Safety Executive. Numbers of mesotheliomas occurring in years before 1968 were not available, and so the rates for 1968 were used for earlier years. The expected number will, therefore, be exaggerated as diagnosed mesotheliomas were rapidly becoming more common in that period.

The social class of men in the armed forces is not 
Table 2 Observed (Obs) deaths and SMRs for officers and other ranks for all three services combined

\begin{tabular}{|c|c|c|c|c|c|c|c|c|c|c|}
\hline \multirow[b]{2}{*}{ Cause of death } & \multirow{2}{*}{$\begin{array}{l}\text { Comparison } \\
\text { Group }\end{array}$} & \multicolumn{3}{|c|}{ Officers } & \multicolumn{3}{|c|}{ Other ranks } & \multicolumn{3}{|c|}{ All ranks } \\
\hline & & Obs & $S M R$ & p Value & Obs & $S M R$ & p Value & Obs & $S M R$ & p Value \\
\hline All neoplasms & $\begin{array}{l}N^{\star} \\
S^{*}\end{array}$ & 186 & 63 & $\begin{array}{c}<0.001 \\
0.06\end{array}$ & 502 & $\begin{array}{l}93 \\
87\end{array}$ & $0 \cdot 10$ & 688 & 82 & $<0.001$ \\
\hline $\begin{array}{l}\text { Other known non-violent } \\
\text { causes }\end{array}$ & $\begin{array}{l}S \dagger \\
\mathbf{N} \\
\mathbf{S}\end{array}$ & 335 & $\begin{array}{l}87 \\
48 \\
65\end{array}$ & $\begin{aligned} & 0.06 \\
< & 0.001 \\
< & 0.001\end{aligned}$ & 1040 & $\begin{array}{l}87 \\
81 \\
80\end{array}$ & $\begin{array}{r}0.002 \\
<0.001 \\
<0.001\end{array}$ & 1375 & $\begin{array}{l}87 \\
70 \\
75\end{array}$ & $\begin{array}{l}<0.001 \\
<0.001 \\
<0.001\end{array}$ \\
\hline Accidents and violence & $\begin{array}{l}\mathrm{N} \\
\mathrm{S}\end{array}$ & 141 & $\begin{array}{l}223 \\
273\end{array}$ & $\begin{array}{l}<0.001 \\
<0.001\end{array}$ & 318 & $\begin{array}{l}117 \\
131\end{array}$ & $\begin{array}{r}0.01 \\
<0.001\end{array}$ & 459 & $\begin{array}{l}137 \\
156\end{array}$ & $\begin{array}{l}<0.001 \\
<0.001\end{array}$ \\
\hline Unknown & $\frac{0}{2}$ & 15 & - & - & 41 & - & - & 56 & - & - \\
\hline All causes & $\begin{array}{l}\mathbf{N} \\
\mathbf{S}\end{array}$ & 677 & $\begin{array}{l}64 \\
87\end{array}$ & $\begin{array}{l}<0.001 \\
<0.001\end{array}$ & 1901 & $\begin{array}{l}91 \\
90\end{array}$ & $\begin{array}{l}<0.001 \\
<0.001\end{array}$ & 2578 & $\begin{array}{l}82 \\
89\end{array}$ & $\begin{array}{l}<0.001 \\
<0.001\end{array}$ \\
\hline
\end{tabular}

*All men in England and Wales.

†Men in social class I for officers, men in social class III (manual and non-manual combined) for other ranks.

the same as that of men in the country as a whole. Officers are conventionally placed in social class I, although some would certainly have had occupations in civilian life that placed them in other social classes. For the purposes of our study we have made the conventional assumption. Similarly, we have assumed that other ranks are drawn predominantly from men who would be in social class III in civilian life. To calculate the numbers of deaths expected in a population with a social class structure similar to that of our study population, we have used social class specific standardised mortality ratios (SMRs) obtained from the decennial supplements ${ }^{1-4}$ to adjust the national mortality for broad causes of death for some of our analyses. To do this we have multiplied the England and Wales mortality in each calendar year and each five year age group by an appropriate linear combination of the relevant age specific SMRs from the decennial supplements occurring before and after that year. We have used the values given for age group 55-64 for all ages above 65 , as the ratios reported in the decennial supplements for men aged over 65 are unreliable. ${ }^{3}$ Based on mortality for all men in England and Wales, only $13 \%$ of our expected deaths occurred in the group older than 65 .

Standardised mortality ratios were calculated by dividing the numbers of deaths observed by the corresponding numbers expected and multiplying by 100. Relative risks (RRs) for the three services adjusting for rank and also RRs for rank adjusting for service were calculated using the GLIM computer program assuming log linear models and Poisson random variation. ${ }^{8}$ Significance levels were calculated assuming Poisson random variation and are 2 sided throughout.

\section{Results}

BROAD CAUSES OF DEATH

When all three services were considered and data for officers and other ranks combined the SMR for all neoplasms, calculated on the basis of mortality for men in the general population of England and Wales, was 82 (table 2). Adjustment for the social class structure of the study population reduced the number of deaths expected slightly and increased the corresponding SMR to 87 , although even this adjusted value remained significantly below 100 $(\mathrm{p}<0.001)$. The SMR for neoplasms based on the national rates for England and Wales appeared to be lower for officers than for other ranks, but adjustment for social class removed this apparent difference and the adjusted SMRs were identical in the two groups.

For non-violent causes of death other than neoplasms mortality was lower than that expected from national rates. Even after adjustment for social class the SMR was only 75 and the deficit remained significant $(p<0.001)$. Although mortality was low for both officers and other ranks, it was lower for officers and remained lower after adjustment for sucial class (adjusted SMRs of 65 in officers and 80 in other ranks; $p$ value for difference $=0.001$ ).

By contrast with non-violent causes of death, mortality from accidents and violence was higher than that expected from national rates $(S M R=137$; $\mathrm{p}<0.001)$ and adjustment for social class increased the excess $(S M R=156 ; p<0.001)$. Although both officers and other ranks experienced an increase, the adjusted SMR for officers was over twice that experienced by other ranks and the number of deaths observed was nearly three times that expected from social class adjusted national rates (SMRs of 273 and 131 among officers and 131 among other ranks; $p$ value for difference $<0.001$ ).

It has been observed in numerous studies of occupational groups that the selection of a healthy population for employment tends to result in a particularly low mortality from diseases in the period shortly after start of employment. It has also been demonstrated that, at any given time after entry to an industry, those who remain in employment tend to have lower mortality from disease than those who have left. ${ }^{9}$ In the present study these healthy worker effects would also be expected to operate, as all men were currently in the services at the time that they 
Table 3 Observed (Obs) deaths and SMRs for officers and other ranks for all three services combined by time since entry to the study for broad causes of death; SMRs are based on mortality for men in social class I for officers, and men in social class III (manual and non-manual combined) for other ranks

\begin{tabular}{|c|c|c|c|c|c|c|c|c|c|}
\hline \multirow[b]{2}{*}{ Cause of death } & \multirow[b]{2}{*}{ Rank } & & \multicolumn{5}{|c|}{ Time since entry to study (y) } & \multirow{2}{*}{$\begin{array}{l}\text { Sign of } \\
\text { trend }\end{array}$} & \multirow{2}{*}{$\begin{array}{l}p \text { Value } \\
\text { for trend }\end{array}$} \\
\hline & & & $0-4$ & $5-9$ & $10-14$ & $15-19$ & $\geqslant 20$ & & \\
\hline \multirow[t]{2}{*}{ All neoplasms } & Officers & $\begin{array}{l}\text { Obs } \\
\text { SMR }\end{array}$ & $\begin{array}{r}8 \\
69\end{array}$ & $\begin{array}{l}12 \\
63\end{array}$ & $\begin{array}{l}20 \\
64\end{array}$ & $\begin{array}{r}53 \\
107\end{array}$ & $\begin{array}{l}93 \\
92\end{array}$ & + & 0.09 \\
\hline & Other ranks & $\begin{array}{l}\text { Obs } \\
\text { SMR }\end{array}$ & $\begin{array}{l}26 \\
75\end{array}$ & $\begin{array}{l}34 \\
62\end{array}$ & $\begin{array}{l}72 \\
82\end{array}$ & $\begin{array}{r}119 \\
87\end{array}$ & $\begin{array}{r}251 \\
96\end{array}$ & + & 0.01 \\
\hline \multirow[t]{2}{*}{$\begin{array}{l}\text { Other known non- } \\
\text { violent causes }\end{array}$} & Officers & $\begin{array}{l}\text { Obs } \\
\text { SMR }\end{array}$ & $\begin{array}{l}13 \\
49\end{array}$ & $\begin{array}{l}26 \\
57\end{array}$ & $\begin{array}{l}53 \\
67\end{array}$ & $\begin{array}{l}75 \\
61\end{array}$ & $\begin{array}{r}168 \\
69\end{array}$ & + & $0 \cdot 18$ \\
\hline & Other ranks & $\begin{array}{l}\text { Obs } \\
\text { SMR }\end{array}$ & $\begin{array}{l}52 \\
66\end{array}$ & $\begin{array}{l}77 \\
63\end{array}$ & $\begin{array}{r}152 \\
75\end{array}$ & $\begin{array}{r}259 \\
81\end{array}$ & $\begin{array}{r}500 \\
86\end{array}$ & + & 0.002 \\
\hline \multirow[t]{2}{*}{ Accidents and violence } & Officers & $\begin{array}{l}\text { Obs } \\
\text { SMR }\end{array}$ & $\begin{array}{r}53 \\
510\end{array}$ & $\begin{array}{r}30 \\
314\end{array}$ & $\begin{array}{r}15 \\
153\end{array}$ & $\begin{array}{r}19 \\
195\end{array}$ & $\begin{array}{r}24 \\
196\end{array}$ & - & $<0.001$ \\
\hline & Other ranks & $\begin{array}{l}\text { Obs } \\
\text { SMR }\end{array}$ & $\begin{array}{r}78 \\
129\end{array}$ & $\begin{array}{r}70 \\
140\end{array}$ & $\begin{array}{r}53 \\
118\end{array}$ & $\begin{array}{r}52 \\
121\end{array}$ & $\begin{array}{r}65 \\
145\end{array}$ & + & 0.84 \\
\hline \multirow[t]{2}{*}{ All causes } & Officers & $\begin{array}{l}\text { Obs } \\
\text { SMR }\end{array}$ & $\begin{array}{r}76 \\
159\end{array}$ & $\begin{array}{l}69 \\
93\end{array}$ & $\begin{array}{l}89 \\
74\end{array}$ & $\begin{array}{r}151 \\
82\end{array}$ & $\begin{array}{r}292 \\
82\end{array}$ & - & 0.001 \\
\hline & Other ranks & $\begin{array}{l}\text { Obs } \\
\text { SMR }\end{array}$ & $\begin{array}{r}158 \\
91\end{array}$ & $\begin{array}{r}190 \\
83\end{array}$ & $\begin{array}{r}283 \\
84\end{array}$ & $\begin{array}{r}441 \\
88\end{array}$ & $\begin{array}{r}829 \\
94\end{array}$ & + & $0 \cdot 18$ \\
\hline
\end{tabular}

were entered into the study, and many men had enlisted only five years previously. To investigate the magnitude and duration of these selection effects we have tabulated social class adjusted SMRs by time since entry to the study for broad causes of death in officers and other ranks (table 3). Among officers the SMR for accidents and violence decreased from 510 in the period $0-4$ years after entry to the study to under 200 more than 10 years after entry, and the trend was highly significant ( $p<0.001)$. By contrast, for neoplasms and other non-violent causes of death the SMRs were low in the first five years after entry to the study and tended to increase subsequently, although for neither cause was the trend statistically significant. For neoplasms, mortality among officers in the periods $15-19$ and more than 20 years after entry was comparable with that for all men in social class I (SMRs of 107 and 92), whereas for other

Table 4 Observed (Obs) deaths and SMRs for officers and other ranks for all three services combined by type and site of neoplasm; SMRs are based on mortality for all men in England and Wales

\begin{tabular}{|c|c|c|c|c|c|c|c|c|c|}
\hline \multirow[b]{2}{*}{ Type and site of neoplasm } & \multicolumn{3}{|c|}{ Officers } & \multicolumn{3}{|c|}{ Other ranks } & \multicolumn{3}{|c|}{ All ranks } \\
\hline & Obs & $S M R$ & p Value & Obs & $S M R$ & p Value & Obs & $S M R$ & p Value \\
\hline $\begin{array}{l}\text { Cancer of mouth, tongue, pharynx } \\
\text { Cancer of oesophagus } \\
\text { Cancer of stomach } \\
\text { Cancer of large intestine and rectum } \\
\text { Cancer of liver } \\
\text { Cancer of pancreas } \\
\text { Cancer of larynx } \\
\text { Cancer of trachea, bronchus, lung and } \\
\text { pleura }\end{array}$ & $\begin{array}{r}5 \\
15 \\
10 \\
21 \\
3 \\
9 \\
4 \\
56\end{array}$ & $\begin{array}{r}127 \\
171 \\
35 \\
71 \\
130 \\
70 \\
147 \\
46\end{array}$ & $\begin{array}{l}0.61 \\
0.06 \\
<0.001 \\
0.12 \\
0.74 \\
0.33 \\
0.54 \\
<0.001\end{array}$ & $\begin{array}{r}8 \\
21 \\
40 \\
56 \\
10 \\
28 \\
7 \\
174\end{array}$ & $\begin{array}{r}98 \\
132 \\
85 \\
100 \\
209 \\
121 \\
146 \\
90\end{array}$ & $\begin{array}{l}1 \cdot 00 \\
0 \cdot 21 \\
0 \cdot 31 \\
1 \cdot 00 \\
0.03 \\
0 \cdot 35 \\
0.35 \\
0 \cdot 16\end{array}$ & $\begin{array}{r}13 \\
36 \\
50 \\
77 \\
13 \\
37 \\
11 \\
230\end{array}$ & $\begin{array}{r}107 \\
146 \\
66 \\
90 \\
184 \\
103 \\
147 \\
73\end{array}$ & $\begin{array}{l}0.77 \\
0.03 \\
0.002 \\
0.39 \\
0.06 \\
0.87 \\
0.27 \\
<0.001\end{array}$ \\
\hline $\begin{array}{l}\text { Skin cancer } \\
\text { Cancer of prostate } \\
\text { Cancer of testis } \\
\text { Cancer of bladder } \\
\text { Cancer of kidney } \\
\text { Tumours of central nervous system } \\
\text { Hodgkin's disease } \\
\text { Non-Hodgkin's lymphoma } \\
\text { Multiple myeloma } \\
\text { Leukaemia } \\
\text { Other specified neoplasms } \\
\text { Unspecified neoplasms }\end{array}$ & $\begin{array}{r}2 \\
13 \\
2 \\
3 \\
6 \\
11 \\
1 \\
6 \\
3 \\
5 \\
2 \\
9\end{array}$ & $\begin{array}{r}69 \\
149 \\
141 \\
33 \\
103 \\
91 \\
30 \\
105 \\
93 \\
67 \\
19 \\
78\end{array}$ & $\begin{array}{l}0.78 \\
0.17 \\
0.66 \\
0.03 \\
1.00 \\
0.78 \\
0.28 \\
1.00 \\
1.00 \\
0.46 \\
0.002 \\
0.56\end{array}$ & $\begin{array}{r}7 \\
16 \\
8 \\
9 \\
16 \\
32 \\
9 \\
13 \\
2 \\
16 \\
15 \\
15\end{array}$ & $\begin{array}{r}79 \\
163 \\
93 \\
67 \\
132 \\
95 \\
69 \\
85 \\
35 \\
77 \\
61 \\
70\end{array}$ & $\begin{array}{l}0.62 \\
0.08 \\
0.87 \\
0.23 \\
0.31 \\
0.80 \\
0.33 \\
0.61 \\
0.14 \\
0.33 \\
0.04 \\
0.16\end{array}$ & $\begin{array}{r}9 \\
29 \\
10 \\
12 \\
22 \\
43 \\
10 \\
19 \\
5 \\
21 \\
17 \\
24\end{array}$ & $\begin{array}{r}77 \\
156 \\
100 \\
53 \\
122 \\
94 \\
61 \\
91 \\
55 \\
75 \\
48 \\
73\end{array}$ & $\begin{array}{l}0.47 \\
0.03 \\
1.00 \\
0.02 \\
0.34 \\
0.71 \\
0.11 \\
0.74 \\
0.19 \\
0.19 \\
0.001 \\
0.12\end{array}$ \\
\hline $\begin{array}{l}\text { Cancers associated with alcohol } \\
\text { (mouth etc, oesophagus, larynx, } \\
\text { liver) }\end{array}$ & 27 & 152 & 0.04 & 46 & 137 & 0.05 & 73 & 142 & 0.004 \\
\hline $\begin{array}{l}\text { Cancers associated with smoking other } \\
\text { than those associated with alcohol } \\
\text { (lung, bladder, kidney, pancreas) }\end{array}$ & 74 & 49 & $<0.001$ & 227 & 94 & 0.32 & 301 & 77 & $<0.001$ \\
\hline Other neoplasms & 85 & 68 & $<0.001$ & 229 & 87 & 0.03 & 314 & 81 & $<0.001$ \\
\hline All neoplasms & 186 & 63 & $<0.001$ & 502 & 93 & $0 \cdot 10$ & 688 & 82 & $<0.001$ \\
\hline
\end{tabular}


non-violent causes of death it remained substantially lower (SMRs of 61 and 69; p $<0.001$ in both periods). For other ranks there was little evidence of a trend in the SMR for accidents and violence. For neoplasms and other non-violent causes of death the pattern was similar to that for officers, except that with the larger numbers the trends were both significant ( $p=0.01$ for neoplasms and 0.002 for other non-violent causes of death). More than 20 years after entry to the study mortality from neoplasms was comparable with that of other men in social class III, but for other non-violent causes of death it remained lower (SMRs of 96 for neoplasms and 86 for other diseases in the period more than 20 years after entry to the study).

\section{NEOPLASMS}

Table 4 shows the results obtained from 20 different types or categories of cancer for all three services combined, both separately for officers and other ranks, and for all ranks combined. In each case the observed mortality is compared with that expected from the experience of all men in England and Wales, irrespective of social class. For two types of cancer the mortality for all ranks was significantly increased (cancer of the oesophagus: $S M R=146, p=0.03$; cancer of the prostate: SMR $=156, p=0.03$ ) and for four types it was significantly decreased (cancer of the stomach: $S M R=66, p=0.002$; cancer of the lung: $S M R=73, p<0.001$; cancer of the bladder: SMR $=53, \mathrm{p}<0.02$; other specified neoplasms: $S M R=48, p=0.001$ ).

One major cause of cancer of the oesophagus is the consumption of alcohol ${ }^{10}$ and it is notable that as well as the significant increase for this site, the SMRs were also greater than 100 for cancers of all other sites for which a definite association with alcohol has been established, ${ }^{10}$ namely, cancers of the mouth, tongue and pharynx, liver, and larynx; among other ranks the increase in liver cancer reached significance $(\mathrm{SMR}=209 ; \quad \mathrm{p}=0.03)$. When all cancers associated with alcohol were considered as a single group the SMR was 142 and the increase was highly significant $(p=0.004)$. For this combined group the SMRs were increased in both officers and other ranks when each was considered separately (values of 152 in officers and 137 in other ranks; $p=0.04$ for officers and 0.05 for other ranks).

The significant deficit of lung cancer when all services and ranks were considered together was due

Table 5 Relative risks for rank adjusted for service, and for service adjusted for rank by type and site of neoplasm; RRs are calculated using SMRs based on mortality rates for all men in England and Wales

\begin{tabular}{|c|c|c|c|c|c|c|}
\hline \multirow[b]{3}{*}{ Type and site of neoplasm } & \multicolumn{2}{|c|}{ Rank adjusting for service } & \multirow{2}{*}{\multicolumn{3}{|c|}{$\begin{array}{l}\text { Service adjusting for rank } \\
R R^{\star}\end{array}$}} & \multirow{3}{*}{$\begin{array}{l}p \text { Value for } \\
\text { heterogeneity }\end{array}$} \\
\hline & \multirow{2}{*}{$\begin{array}{l}R R \text { officers } \\
\text { compared with } \\
\text { other rankst }\end{array}$} & \multirow{2}{*}{$\begin{array}{l}\text { p Value } \\
\text { for } \\
\text { difference }\end{array}$} & & & & \\
\hline & & & $R N$ & Army & $R A F$ & \\
\hline $\begin{array}{l}\text { Cancer of mouth, tongue, pharynx } \\
\text { Cancer of oesophagus } \\
\text { Cancer of stomach } \\
\text { Cancer of large intestine and rectum } \\
\text { Cancer of liver } \\
\text { Cancer of pancreas } \\
\text { Cancer of larynx } \\
\text { Cancer of trachea, bronchus, lung }\end{array}$ & $\begin{array}{l}2.14 \\
1.43 \\
0.45 \\
0.77 \\
0.62 \\
0.57 \\
1.15\end{array}$ & $\begin{array}{l}0.22 \\
0.32 \\
0.02 \\
0.32 \\
0.46 \\
0.13 \\
0.83\end{array}$ & $\begin{array}{l}2.76 \\
1.43 \\
1.39 \\
1.15 \\
0.86 \\
1.03 \\
1.25\end{array}$ & $\begin{array}{l}0.62 \\
0.62 \\
0.67 \\
1.12 \\
1.92 \\
0.81 \\
1.14\end{array}$ & $\begin{array}{l}0.58 \\
1.14 \\
1.08 \\
0.78 \\
0.61 \\
1.19 \\
0.70\end{array}$ & $\begin{array}{l}0.04 \\
0.37 \\
0.32 \\
0 \cdot 27 \\
0.28 \\
0.76 \\
0.68\end{array}$ \\
\hline $\begin{array}{l}\text { and pleura } \\
\text { Skin cancer } \\
\text { Cancer of prostate } \\
\text { Cancer of testis } \\
\text { Cancer of bladder } \\
\text { Cancer of kidney } \\
\text { Tumours of central nervous system } \\
\text { Hodgkin's disease } \\
\text { Non-Hodgkin's lymphoma } \\
\text { Multiple myeloma } \\
\text { Leukaemia } \\
\text { Other specified neoplasms } \\
\text { Unspecified neoplasms }\end{array}$ & $\begin{array}{l}0.54 \\
0.91 \\
0.97 \\
1.92 \\
0.51 \\
0.85 \\
0.96 \\
0.39 \\
0.98 \\
2.35 \\
0.94 \\
0.34 \\
1.55\end{array}$ & $\begin{array}{l}<0.001 \\
0 \cdot 91 \\
0 \cdot 95 \\
0 \cdot 45 \\
0 \cdot 31 \\
0 \cdot 74 \\
0.91 \\
0 \cdot 33 \\
0.96 \\
0 \cdot 36 \\
0 \cdot 91 \\
0 \cdot 12 \\
0.34\end{array}$ & $\begin{array}{l}1 \cdot 13 \\
0.99 \\
1 \cdot 70 \\
1 \cdot 44 \\
1.07 \\
1 \cdot 19 \\
0.99 \\
0.76 \\
0.53 \\
0.68 \\
1 \cdot 10 \\
1.26 \\
2 \cdot 50\end{array}$ & $\begin{array}{l}0.94 \\
1.39 \\
0 \cdot 34 \\
1.38 \\
1 \cdot 14 \\
0.94 \\
1.09 \\
1.38 \\
1.44 \\
1.26 \\
1.25 \\
0.90 \\
0.38\end{array}$ & $\begin{array}{l}0.94 \\
0.73 \\
1.71 \\
0.50 \\
0.82 \\
0.90 \\
0.93 \\
0.95 \\
1.32 \\
1.16 \\
0.72 \\
0.88 \\
1.05\end{array}$ & $\begin{array}{l}0.40 \\
0.78 \\
0.12 \\
0.37 \\
0.89 \\
0.83 \\
0.94 \\
0.80 \\
0.21 \\
0.88 \\
0.60 \\
0.78 \\
0.03\end{array}$ \\
\hline $\begin{array}{l}\text { Cancers associated with alcohol } \\
\text { (mouth etc, oesophagus, larynx, } \\
\text { liver) } \\
\text { Cancers associated with smoking other } \\
\text { than those associated with alcohol }\end{array}$ & $1 \cdot 29$ & $0 \cdot 32$ & $1 \cdot 35$ & 0.91 & 0.81 & 0.15 \\
\hline $\begin{array}{l}\text { (lung, bladder, kidney, pancreas) } \\
\text { Other neoplasms }\end{array}$ & $\begin{array}{l}0 \cdot 55 \\
0 \cdot 83\end{array}$ & $\begin{array}{c}<0.001 \\
0.17\end{array}$ & $\begin{array}{l}1 \cdot 12 \\
1 \cdot 14\end{array}$ & $\begin{array}{l}0.93 \\
0.95\end{array}$ & $\begin{array}{l}0.96 \\
0.92\end{array}$ & $\begin{array}{l}0 \cdot 39 \\
0 \cdot 20\end{array}$ \\
\hline All neoplasms & 0.73 & $<0.001$ & $1 \cdot 15$ & 0.94 & 0.92 & 0.02 \\
\hline
\end{tabular}

«Values are scaled so product for all three services is 1.00 .

†Values for other ranks 1.00 . 
primarily to a large deficit among officers in whom mortality was less than half that expected from national rates $(S M R=46 ; p<0.001$ ), whereas for other ranks mortality was $90 \%$ of that expected. Cancers of the bladder, kidney, and pancreas are also associated with smoking but not with consumption of alcohol, and when they were considered together as a group the pattern was similar to that for lung cancer. For officers mortality was lower than that expected nationally, although the deficit was not quite significant $(\mathrm{SMR}=64 ; \mathrm{p}=0.06$ based on 18 deaths); for other ranks mortality was similar to the national value $(S M R=109 ; p=0.57$ based on 53 deaths).

For neoplasms other than those associated with alcohol or smoking, there was a significant overall deficit (SMR $=81 ; p<0.001)$. When officers and other ranks were considered separately, mortality in both groups was significantly reduced compared with that expected from national rates (SMRs of 68 among officers and 87 among other ranks; $p<0.001$ for officers, $p=0.03$ for other ranks). Among the individual sites in this group there were significant deficits both overall and among officers considered alone for stomach cancer, and both overall and among officers and other ranks considered separately for other specified neoplasms.

After adjusting for any differences between the services, mortality from all neoplasms among officers was $73 \%$ that of other ranks, and the deficit was highly significant ( $p<0.001$; see table 5$)$. This was primarily due to lower mortality from cancers associated with smoking, other than those associated with alcohol. For these cancers mortality among officers was just over half that of other ranks ( $R R=0.55 ; p<0.001)$. When the four sites of cancer were considered individually, the pattern for lung cancer was similar to that for all cancers associated with smoking, other than those associated with alcohol. For the other sites in this group (pancreas, bladder, and kidney) mortality among officers was also lower than that in other ranks (RRs $0.57,0.51$, and 0.85 ) but the individual differences were not statistically significant. Among other types and sites of neoplasm, mortality from stomach cancer was significantly reduced in officers compared with other ranks $(R R=0.45 ; p=0.02)$.

When the three services were considered separately, mortality from all neoplasms in the RN was almost equal to that expected on the basis of national death rates for all men $(S M R=99$; see table 6 ). For cancers associated with smoking, other than those associated with alcohol, and also for neoplasms other than those established as associated with alcohol or smoking, mortality in the $\mathrm{RN}$ was also close to that expected on the basis of national death rates

Table 6 Observed (Obs) deaths and SMRs in the three services for officers and other ranks combined by type and site of neoplasm; SMRs are based on mortality for all men in England and Wales

\begin{tabular}{|c|c|c|c|c|c|c|c|c|c|}
\hline \multirow[b]{2}{*}{ Type and site of neoplasm } & \multicolumn{3}{|l|}{$R N$} & \multicolumn{3}{|c|}{ Army } & \multicolumn{3}{|c|}{$R A F$} \\
\hline & Obs & $S M R$ & p Value & Obs & $S M R$ & p Value & Obs & $S M R$ & p Value \\
\hline $\begin{array}{l}\text { Cancer of mouth, tongue, pharynx } \\
\text { Cancer of oesophagus } \\
\text { Cancer of stomach } \\
\text { Cancer of large intestine and rectum } \\
\text { Cancer of liver } \\
\text { Cancer of pancreas } \\
\text { Cancer of larynx } \\
\text { Cancer of trachea, bronchus, lung and } \\
\text { pleura } \\
\text { Skin cancer } \\
\text { Cancer of prostate } \\
\text { Cancer of testis } \\
\text { Cancer of bladder } \\
\text { Cancer of kidney } \\
\text { Tumours of central nervous system } \\
\text { Hodgkin's disease } \\
\text { Non-Hodgkin's lymphoma } \\
\text { Multiple myeloma } \\
\text { Leukaemia } \\
\text { Other specified neoplasms } \\
\text { Unspecified neoplasms }\end{array}$ & $\begin{array}{r}9 \\
15 \\
24 \\
35 \\
5 \\
14 \\
5 \\
98 \\
4 \\
10 \\
6 \\
5 \\
10 \\
18 \\
4 \\
4 \\
1 \\
10 \\
9 \\
14\end{array}$ & $\begin{array}{r}196 \\
168 \\
90 \\
112 \\
189 \\
108 \\
186 \\
\\
90 \\
82 \\
178 \\
128 \\
66 \\
147 \\
96 \\
55 \\
47 \\
31 \\
86 \\
65 \\
117\end{array}$ & $\begin{array}{l}0.05 \\
0.06 \\
0.63 \\
0.53 \\
0.20 \\
0.78 \\
0.20 \\
\\
0.31 \\
0.82 \\
0.08 \\
0.64 \\
0.38 \\
0.24 \\
0.91 \\
0.27 \\
0.13 \\
0.28 \\
0.67 \\
0.23 \\
0.56\end{array}$ & $\begin{array}{r}1 \\
3 \\
4 \\
13 \\
4 \\
4 \\
2 \\
\\
30 \\
2 \\
1 \\
2 \\
2 \\
3 \\
7 \\
2 \\
4 \\
1 \\
4 \\
2 \\
1\end{array}$ & $\begin{array}{r}55 \\
81 \\
36 \\
102 \\
376 \\
74 \\
177 \\
\\
63 \\
113 \\
36 \\
137 \\
59 \\
112 \\
104 \\
87 \\
129 \\
74 \\
97 \\
38 \\
20\end{array}$ & $\begin{array}{l}0.73 \\
0.81 \\
0.02 \\
1.00 \\
0.02 \\
0.67 \\
0.31 \\
\\
0.01 \\
1.00 \\
0.38 \\
0.66 \\
0.60 \\
1.00 \\
1.00 \\
1.00 \\
0.56 \\
1.00 \\
1.00 \\
0.19 \\
0.07\end{array}$ & $\begin{array}{r}3 \\
18 \\
22 \\
29 \\
4 \\
19 \\
4 \\
\\
102 \\
3 \\
18 \\
2 \\
5 \\
9 \\
18 \\
4 \\
11 \\
3 \\
7 \\
6 \\
9\end{array}$ & $\begin{array}{r}53 \\
149 \\
58 \\
70 \\
119 \\
108 \\
108 \\
\\
64 \\
59 \\
178 \\
51 \\
43 \\
106 \\
89 \\
59 \\
117 \\
68 \\
56 \\
37 \\
56\end{array}$ & $\begin{array}{c}0.30 \\
0.11 \\
0.01 \\
0.05 \\
0.78 \\
0.81 \\
1.00 \\
\\
<0.001 \\
0.40 \\
0.03 \\
0.45 \\
0.04 \\
0.86 \\
0.66 \\
0.34 \\
0.62 \\
0.64 \\
0.12 \\
0.01 \\
0.08\end{array}$ \\
\hline $\begin{array}{l}\text { Cancers associated with alcohol } \\
\text { (mouth etc, oesophagus, larynx, liver) } \\
\text { Cancers associated with smoking other } \\
\text { than those associated with alcohol } \\
\text { (lung, bladder, kidney, pancreas) } \\
\text { Other neoplasms }\end{array}$ & $\begin{array}{r}34 \\
127 \\
139\end{array}$ & $\begin{array}{l}93 \\
94\end{array}$ & $\begin{array}{l}0.44 \\
0.46\end{array}$ & $\begin{array}{l}39 \\
43\end{array}$ & $\begin{array}{l}66 \\
74\end{array}$ & $\begin{array}{l}0.01 \\
0.05\end{array}$ & $\begin{array}{l}135 \\
132\end{array}$ & $\begin{array}{l}68 \\
72\end{array}$ & $\begin{array}{l}<0.001 \\
<0.001\end{array}$ \\
\hline All neoplasms & 300 & 99 & $0 \cdot 86$ & 92 & 74 & 0.003 & 296 & 73 & $<0.001$ \\
\hline
\end{tabular}


Table 7 Observed deaths (Obs), expected deaths (Exp) and SMRs for deaths with mesothelioma mentioned on the death certificate by rank and service. Expected values are calculated from rates for all men in Britain from 1968, and using 1968 rates for earlier years

\begin{tabular}{lllrl}
\hline Service and rank & Obs & Exp & SMR & p Value \\
\hline RN - officers & 2 & 0.29 & 698 & 0.03 \\
RN - other ranks & 5 & 1.77 & 282 & 0.03 \\
Army and RAF & 0 & 3.16 & 0 & 0.08 \\
$\begin{array}{l}\text { All services and } \\
\text { ranks }\end{array}$ & 7 & 5.22 & 134 & 0.51 \\
\hline
\end{tabular}

(SMRs of 93 and 94). For cancers associated with alcohol, however, there was a substantial increase in mortality that was highly significant $(S M R=181$; $p=0.002)$. When data for each of the four sites contributing to this group were examined individually the SMRs for the RN were above 100 in all four, although only for cancer of the mouth, tongue, and pharynx was the increase significant $(\mathrm{SMR}=196 ; \mathrm{p}=0.05)$.

In the Army, mortality from all neoplasms combined was substantially less than that expected from national rates $(S M R=74 ; p=0.003)$. This was due both to very low mortality from cancers associated with smoking, other than those associated with alcohol $(S M R=66 ; p=0.01)$, and to low mortality from neoplasms other than those associated with smoking or alcohol (SMR $=74 ; p=0.05)$. By contrast, mortality from cancers associated with alcohol was raised in the Army compared with the national rates although the increase was less than that observed in the RN and was not significant statistically (SMR $=130 ; p=0.47)$. When mortality in the Army was considered for the various sites of cancer individually, there was a deficit of stomach cancer (SMR $=36 ; p=0.02$ ) and also of lung cancer $(S M R=63: p=0.01)$. By contrast, there was a significant increase in liver cancer. Although there were only four deaths from liver cancer mortality was nearly three times the national figure $(S M R=376$; $\mathrm{p}=0.02$ ).

In the RAF the SMRs for all neoplasms and for the three broad subgroups were similar to those for the Army; mortality was low for all neoplasms, all cancers associated with smoking other than those associated with alcohol, and all neoplasms other than those associated with alcohol or smoking (SMRs of 73,68 , and $72 ; \mathrm{p}<0.001$ for all three), whereas mortality from cancers associated with alcohol was raised although the increase was less than that in the

Table 8 Observed (Obs) deaths and SMRs for officers and other ranks for all three services combined for causes of death other than neoplasms; SMRs are based on mortality for all men in England and Wales

\begin{tabular}{|c|c|c|c|c|c|c|c|c|c|}
\hline \multirow[b]{2}{*}{ Cause of death } & \multicolumn{3}{|c|}{ Officers } & \multicolumn{3}{|c|}{ Other ranks } & \multicolumn{3}{|c|}{ All ranks } \\
\hline & Obs & $S M R$ & p Value & Obs & $S M R$ & p Value & Obs & $S M R$ & p Value \\
\hline $\begin{array}{l}\text { Diseases strongly related to smoking: } \\
\text { Coronary heart disease } \\
\text { Bronchitis, emphysema and chronic } \\
\text { obstructive lung disease } \\
\text { Aortic aneurysm } \\
\text { All diseases strongly related to smoking }\end{array}$ & $\begin{array}{r}199 \\
4 \\
15 \\
218\end{array}$ & $\begin{array}{r}55 \\
\\
8 \\
140 \\
51\end{array}$ & $\begin{array}{c}<0.001 \\
<0.001 \\
0.22 \\
<0.001\end{array}$ & $\begin{array}{r}589 \\
44 \\
13 \\
646\end{array}$ & $\begin{array}{l}88 \\
\\
68 \\
84 \\
86\end{array}$ & $\begin{array}{c}0.001 \\
0.01 \\
0.53 \\
<0.001\end{array}$ & $\begin{array}{r}788 \\
48 \\
28 \\
864\end{array}$ & $\begin{array}{r}76 \\
42 \\
107 \\
73\end{array}$ & $\begin{array}{c}<0.001 \\
<0.001 \\
0.77 \\
<0.001\end{array}$ \\
\hline $\begin{array}{l}\text { Diseases related to alcohol: } \\
\text { Cirrhosis of liver, alcoholism and } \\
\text { alcoholic psychosis }\end{array}$ & 6 & 80 & 0.72 & 26 & 125 & 0.27 & 32 & 113 & 0.51 \\
\hline $\begin{array}{l}\text { Other diseases: } \\
\text { Infections and parasitic diseases } \\
\text { Diseases of nervous system } \\
\text { Other diseases of circulatory system } \\
\text { Other diseases of respiratory system } \\
\text { Other diseases of digestive system } \\
\text { Remaining diseases } \\
\text { All other diseases }\end{array}$ & $\begin{array}{r}3 \\
5 \\
66 \\
19 \\
8 \\
10 \\
111\end{array}$ & $\begin{array}{l}30 \\
39 \\
48 \\
40 \\
38 \\
31 \\
43\end{array}$ & $\begin{aligned} & 0.02 \\
& 0.02 \\
< & 0.001 \\
< & 0.001 \\
& 0.002 \\
< & 0.001 \\
< & 0.001\end{aligned}$ & $\begin{array}{r}17 \\
16 \\
199 \\
57 \\
43 \\
36 \\
368\end{array}$ & $\begin{array}{r}74 \\
44 \\
82 \\
67 \\
100 \\
44 \\
72\end{array}$ & $\begin{aligned} & 0.25 \\
&< 0.001 \\
& 0.004 \\
& 0.002 \\
& 1.00 \\
&< 0.001 \\
&< 0.001\end{aligned}$ & $\begin{array}{r}20 \\
21 \\
265 \\
76 \\
51 \\
46 \\
479\end{array}$ & $\begin{array}{l}61 \\
43 \\
70 \\
58 \\
80 \\
40 \\
62\end{array}$ & $\begin{array}{c}0.02 \\
<0.001 \\
<0.001 \\
<0.001 \\
0.10 \\
<0.001 \\
<0.001\end{array}$ \\
\hline $\begin{array}{l}\text { All known non-violent causes, other } \\
\text { than neoplasms }\end{array}$ & 335 & 48 & $<0.001$ & 1040 & 81 & $<0.001$ & 1375 & 70 & $<0.001$ \\
\hline $\begin{array}{l}\text { Accidents and violence: } \\
\text { Motor vehicle traffic accidents } \\
\text { Drowning and water transport } \\
\text { accidents } \\
\text { Air accidents } \\
\text { Suicide } \\
\text { Other injury and poisoning } \\
\text { All accidents and violence }\end{array}$ & $\begin{array}{r}22 \\
2 \\
66 \\
25 \\
26 \\
141\end{array}$ & $\begin{array}{r}1.20 \\
\\
62 \\
12,150 \\
132 \\
117 \\
223\end{array}$ & $\begin{array}{c}0.41 \\
0.60 \\
<0.001 \\
0.20 \\
0.46 \\
<0.001\end{array}$ & $\begin{array}{r}104 \\
\\
21 \\
16 \\
74 \\
103 \\
318\end{array}$ & $\begin{array}{r}115 \\
145 \\
471 \\
99 \\
116 \\
117\end{array}$ & $\begin{array}{c}0.17 \\
0.11 \\
<0.001 \\
1.00 \\
0.14 \\
0.01\end{array}$ & $\begin{array}{r}126 \\
23 \\
82 \\
99 \\
129 \\
459\end{array}$ & $\begin{array}{r}115 \\
130 \\
2079 \\
106 \\
116 \\
137\end{array}$ & $\begin{array}{c}0.11 \\
0.23 \\
<0.001 \\
0.57 \\
0.10 \\
<0.001\end{array}$ \\
\hline All known causes, other than neoplasms & 476 & 63 & $<0.001$ & 1358 & 87 & $<0.001$ & 1834 & 79 & $<0.001$ \\
\hline
\end{tabular}


other two services, and was not significant $(S M R=117 ; p=0.42)$. When the various sites of cancer were examined individually mortality in the RAF was significantly reduced compared with national rates for cancers of the stomach, large intestine and rectum, lung, bladder, and other specified neoplasms, but it was significantly increased for cancer of the prostate $(S M R=178$; $\mathrm{p}=0.03$ ).

After adjusting for any differences between officers and other ranks, there was significant heterogeneity between the three services in the RR for mortality from all neoplasms $(p=0.02$; table 5$)$. Relative risks in the Army and the RAF took similar values ( 0.94 and 0.92$)$, but the $R R$ for the $R N$ was considerably higher $(1 \cdot 15)$. When neoplasms were subdivided into the three broad groups previously considered a similar pattern was found in each of them, but with the smaller numbers of deaths in each group there was no longer significant heterogeneity between the three services (table 5). When the various sites and types of cancer were considered individually, there was significant heterogeneity between the three services for cancers of the mouth, tongue, and pharynx, and for neoplasms of unspecified site, and in both groups RRs for the RN were raised compared with those for the other two services.

To investigate the reason for the increase in deaths from neoplasms of unspecified site in the RN compared with the other two services, the death certificates in this category were inspected individually. Of the 14 certificates corresponding to deaths in the $\mathrm{RN}$ four mentioned the word mesothelioma, whereas it was not mentioned on any of the 10 certificates for members of the other two services. None of the four certificates mentioned the site of the mesothelioma. All death certificates in the study were then searched for mention of mesothelioma, and three more were found in which death had been attributed to mesothelioma of the pleura and which had therefore been grouped with cancer of the lung in tables 4-6. These three were also for men in the RN. Two of the seven deaths were among officers, and the remaining five

Table 9 Relative risks for rank adjusted for service, and for service adjusted for rank for causes of death other than neoplasms; RRs are calculated using SMRs based on mortality for all men in England and Wales

\begin{tabular}{|c|c|c|c|c|c|c|}
\hline \multirow[b]{3}{*}{ Cause of death } & \multicolumn{2}{|c|}{ Rank adjusting for service } & \multicolumn{3}{|c|}{ Service adjusting for rank } & \multirow{3}{*}{$\begin{array}{l}p \text { Value for } \\
\text { heterogeneity }\end{array}$} \\
\hline & \multirow{2}{*}{$\begin{array}{l}R R \text { for officers } \\
\text { compared with } \\
\text { other ranks } \dagger\end{array}$} & \multirow{2}{*}{$\begin{array}{l}p \text { Value } \\
\text { for } \\
\text { difference }\end{array}$} & \multicolumn{3}{|l|}{$R R^{\star}$} & \\
\hline & & & $R N$ & Army & $R A F$ & \\
\hline \multicolumn{7}{|l|}{ Diseases strongly related to smoking: } \\
\hline $\begin{array}{l}\text { Coronary heart disease } \\
\text { Bronchitis, emphysema and chronic }\end{array}$ & 0.63 & $<0.001$ & 1.01 & 1.03 & 0.96 & 0.69 \\
\hline $\begin{array}{l}\text { obstructive lung disease } \\
\text { Aortic aneurysm }\end{array}$ & $\begin{array}{l}0.13 \\
1.50\end{array}$ & $\begin{array}{c}<0.001 \\
0.30\end{array}$ & $\begin{array}{l}1 \cdot 29 \\
0.83\end{array}$ & $\begin{array}{l}1 \cdot 28 \\
0 \cdot 81\end{array}$ & $\begin{array}{l}0.60 \\
1.49\end{array}$ & $\begin{array}{l}0.05 \\
0.33\end{array}$ \\
\hline All diseases strongly related to smoking & 0.60 & $<0.001$ & 1.02 & $1 \cdot 03$ & 0.95 & 0.51 \\
\hline \multicolumn{7}{|l|}{ Diseases related to alcohol: } \\
\hline $\begin{array}{l}\text { Cirrhosis of liver, alcoholism and } \\
\text { alcoholic psychosis }\end{array}$ & $1 \cdot 15$ & $0 \cdot 77$ & $6 \cdot 69 \ddagger$ & & & $<0.001$ \\
\hline \multicolumn{7}{|l|}{ Other diseases: } \\
\hline Infections and parasitic diseases & 0.54 & $0 \cdot 31$ & 1.97 & 0.53 & 0.97 & $0 \cdot 18$ \\
\hline Diseases of nervous system & $0 \cdot 78$ & 0.63 & 0.75 & $1 \cdot 27$ & 1.05 & 0.67 \\
\hline Other diseases of circulatory system & 0.57 & $<0.001$ & 0.88 & 1.33 & $0 \cdot 86$ & 0.03 \\
\hline Other diseases of respiratory system & 0.63 & 0.08 & $1 \cdot 15$ & 0.87 & 1.00 & 0.73 \\
\hline $\begin{array}{l}\text { Other diseases of digestive system } \\
\text { Remaining diseases }\end{array}$ & 0.41 & 0.02 & 1.09 & $1 \cdot 24$ & 0.74 & $0 \cdot 33$ \\
\hline Remaining diseases & $0 \cdot 68$ & $0 \cdot 28$ & 1.03 & 0.83 & $1 \cdot 17$ & $0 \cdot 77$ \\
\hline All other diseases & 0.59 & $<0.001$ & 0.96 & $1 \cdot 16$ & $0 \cdot 89$ & $0 \cdot 14$ \\
\hline \multicolumn{7}{|l|}{ All known non-violent causes, other } \\
\hline \multicolumn{7}{|l|}{ Accidents and violence: } \\
\hline \multicolumn{7}{|l|}{$\begin{array}{l}\text { Motor vehicle traffic accidents } \\
\text { Drowning and water transport }\end{array}$} \\
\hline $\begin{array}{l}\text { Drowning and water transport } \\
\text { accidents }\end{array}$ & $0 \cdot 75$ & $0 \cdot 70$ & $3 \cdot 13$ & & & 0.002 \\
\hline Air accidents & $16 \cdot 46$ & $<0.001$ & 0.34 & 1.06 & $2 \cdot 76$ & $<0.001$ \\
\hline Suicide & 1.67 & 0.04 & 1.53 & $0 \cdot 87$ & 0.75 & 0.01 \\
\hline Other injury and poisoning & 1.06 & $0 \cdot 80$ & 1.03 & $1 \cdot 26$ & 0.77 & $0 \cdot 12$ \\
\hline All accidents and violence & 1.96 & $<0.001$ & 1.05 & 1.02 & 0.93 & 0.52 \\
\hline All known causes, other than neoplasms & $0 \cdot 74$ & $<0.001$ & 1.04 & 1.05 & 0.92 & 0.03 \\
\hline
\end{tabular}

*Values are scaled so that product for all three services is 1.00 .

+Value for other ranks 1.00 .

$\ddagger$ There were no deaths in the Army from this cause; therefore the RR for the RN compared with the other two services combined is shown. 
among other ranks. Less than 0.29 and 1.77 such deaths would have been expected in these two groups (table 7 and methods section) so that the increase in the RN was statistically significant in both officers and other ranks $(\mathrm{p}<0.03)$.

\section{NON-VIOLENT CAUSES OF DEATH OTHER THAN NEO- PLASMS}

When other non-violent causes of death were subdivided into diseases strongly related to smoking, diseases related to alcohol, and all other diseases, there were significant deficits relative to national rates among both officers and other ranks for diseases strongly related to smoking, and for all diseases other than those strongly related to smoking or alcohol (table 8). Also, deficits occurred for many of the individual diseases and disease categories considered in these groups among both officers and other ranks (table 8). In contrast, the SMR for diseases related to alcohol was above 100 for all ranks combined and for other ranks, but the increases were not significant (all ranks: $\quad S M R=113, p=0.51$; other ranks: $S M R=125, p=0 \cdot 27)$.

After allowing for differences between the services, officers had substantially lower mortality compared with other ranks for all non-violent causes of death other than neoplasms, all diseases strongly related to smoking, and all diseases other than those related to smoking or alcohol (RRs of $0 \cdot 61,0 \cdot 60$, and $0.59 ; \mathrm{p}<0.001$ for all three groupings; table 9). Also, officers had lower rates than other ranks for many of the individual diseases or groups of diseases examined and for several the difference was statistically significant.

When the three services were considered separately, mortality from all non-violent causes other than neoplasms, all diseases strongly related to smoking, and all diseases other than those related to smoking or alcohol was significantly reduced compared with national rates in all three services (table 10). For all three services mortality was low for many of the individual diseases and disease groups in these two categories. For diseases related to alcohol, mortality was low for the Army and the RAF (Army: $S M R=0, p=0.02$; RAF: $S M R=48, p=0.07$ ). By contrast, mortality from diseases related to alcohol in the RN was over twice that expected on the basis of national rates $(S M R=229$; $p<0.001)$.

After adjusting for any differences between officers and other ranks, there was no significant heterogeneity between the three services for mortality from all non-violent causes other than neo-

Table 10 Observed (Obs) deaths and SMRs in the three services for officers and other ranks combined for causes of death other than neoplasms; SMRs are based on mortality for all men in England and Wales

\begin{tabular}{|c|c|c|c|c|c|c|c|c|c|}
\hline \multirow[b]{2}{*}{ Cause of death } & \multicolumn{3}{|l|}{$R N$} & \multicolumn{3}{|c|}{ Army } & \multicolumn{3}{|c|}{$R A F$} \\
\hline & Obs & $S M R$ & p Value & Obs & $S M R$ & p Value & Obs & $S M R$ & p Value \\
\hline $\begin{array}{l}\text { Diseases strongly related to smoking: } \\
\text { Coronary heart disease } \\
\text { Bronchitis, emphysema and chronic } \\
\text { obstructive lung disease } \\
\text { Aortic aneurysm } \\
\text { All diseases strongly related to smoking }\end{array}$ & $\begin{array}{r}316 \\
\\
26 \\
6 \\
348\end{array}$ & $\begin{array}{l}70 \\
69 \\
82\end{array}$ & $\begin{aligned} 0.001 \\
\\
0.07 \\
0.40 \\
<0.001\end{aligned}$ & $\begin{array}{r}118 \\
8 \\
3 \\
129\end{array}$ & $\begin{array}{l}76 \\
46 \\
76 \\
73\end{array}$ & $\begin{aligned} 0.002 \\
\\
0.02 \\
0.80 \\
<0.001\end{aligned}$ & $\begin{array}{r}354 \\
14 \\
19 \\
387\end{array}$ & $\begin{array}{r}70 \\
23 \\
140 \\
67\end{array}$ & $\begin{array}{c}<0.001 \\
<0.001 \\
0.17 \\
<0.001\end{array}$ \\
\hline $\begin{array}{l}\text { Diseases related to alcohol: } \\
\text { Cirrhosis of liver, alcoholism and } \\
\text { alcoholic psychosis }\end{array}$ & 26 & 229 & $<0.001$ & 0 & 0 & $0 \cdot 02$ & 6 & 48 & 0.07 \\
\hline $\begin{array}{l}\text { Other Diseases: } \\
\text { Infections and parasitic diseases } \\
\text { Diseases of nervous system } \\
\text { Other diseases of circulatory system } \\
\text { Other diseases of respiratory system } \\
\text { Other diseases of digestive system } \\
\text { Remaining diseases } \\
\text { All other diseases }\end{array}$ & $\begin{array}{r}13 \\
7 \\
99 \\
33 \\
25 \\
19 \\
196\end{array}$ & $\begin{array}{r}96 \\
35 \\
72 \\
68 \\
102 \\
41 \\
67\end{array}$ & $\begin{array}{l}0.89 \\
0.001 \\
0.001 \\
0.03 \\
0.92 \\
<0.001 \\
<0.001\end{array}$ & $\begin{array}{r}1 \\
4 \\
53 \\
9 \\
9 \\
5 \\
81\end{array}$ & $\begin{array}{l}22 \\
56 \\
95 \\
46 \\
96 \\
31 \\
72\end{array}$ & $\begin{array}{l}0 \cdot 10 \\
0 \cdot 27 \\
0 \cdot 74 \\
0 \cdot 01 \\
1 \cdot 00 \\
0.002 \\
<0.002\end{array}$ & $\begin{array}{r}6 \\
10 \\
113 \\
34 \\
17 \\
22 \\
202\end{array}$ & $\begin{array}{l}41 \\
46 \\
61 \\
53 \\
56 \\
43 \\
55\end{array}$ & $\begin{aligned} & 0.01 \\
& 0.01 \\
&< 0.001 \\
&< 0.001 \\
& 0.01 \\
&< 0.001 \\
&< 0.001\end{aligned}$ \\
\hline $\begin{array}{l}\text { All known non-violent causes, other } \\
\text { than neoplasms }\end{array}$ & 570 & 79 & $<0.001$ & 210 & 72 & $<0.001$ & 595 & 62 & $<0.001$ \\
\hline $\begin{array}{l}\text { Accidents and violence: } \\
\text { Motor vehicle traffic accidents } \\
\text { Drowning and water transport } \\
\text { accidents } \\
\text { Air accidents } \\
\text { Suicide } \\
\text { Other injury and poisoning } \\
\text { All accidents and violence }\end{array}$ & $\begin{array}{r}57 \\
\\
19 \\
5 \\
57 \\
61 \\
199\end{array}$ & $\begin{array}{l}113 \\
237 \\
249 \\
139 \\
125 \\
132\end{array}$ & $\begin{array}{l}0.40 \\
0.001 \\
0.05 \\
0.02 \\
0.10 \\
<0.001\end{array}$ & $\begin{array}{r}24 \\
1 \\
9 \\
12 \\
25 \\
71\end{array}$ & $\begin{array}{r}160 \\
\\
39 \\
1772 \\
88 \\
154 \\
148\end{array}$ & $\begin{array}{l}0.04 \\
0.39 \\
<0.001 \\
0.69 \\
0.04 \\
0.002\end{array}$ & $\begin{array}{r}45 \\
\\
3 \\
68 \\
30 \\
43 \\
189\end{array}$ & $\begin{array}{r}103 \\
\\
42 \\
4755 \\
78 \\
94 \\
139\end{array}$ & $\begin{array}{c}0.82 \\
\\
0.13 \\
<0.001 \\
0.17 \\
0.71 \\
<\theta .001\end{array}$ \\
\hline All known causes, other than neoplasms & 769 & 88 & $<0.001$ & 281 & 82 & 0.001 & 784 & 72 & $<0.001$ \\
\hline
\end{tabular}


plasms, diseases strongly related to smoking, or all diseases other than those related to smoking or alcohol ( $\mathrm{p}$ for heterogeneity $0.09,0.51$, and 0.14 ; table 9). There was significant heterogeneity for bronchitis, emphysema, and chronic obstructive lung disease, with mortality in the RAF about half that of the other two services (RRs: RN: 1.29; Army: 1.28; RAF: 0.60 ; $p$ for heterogeneity $=0.05$ ), and also for diseases of the circulatory system other than coronary heart disease and aortic aneurysm with mortality in the Army about $50 \%$ greater than in the RN or the RAF (RRs: RN: 0.88; Army: 1.33; RAF: 0.86 ; $p$ for heterogeneity $=0.03$ ). For diseases related to alcohol there was highly significant heterogeneity between the three services, with mortality in the RN 6.69 times that in the other two services combined ( $p$ for heterogeneity $<0.001$ ).

\section{ACCIDENTS AND VIOLENCE}

When all ranks and all three services were combined, mortality from each of the five individual categories considered was raised compared with national rates, although only for air accidents was the increase significant $(S M R=2079 ; p<0.001$; table 8). The increase in air accidents was greatest among officers but it also affected other ranks (officers: SMR $=12,150 ; \quad \mathrm{p}<0.001 ; \quad$ other ranks: SMR $=471 ; p<0.001)$. After allowing for differences between the three services, mortality remained higher in officers than in other ranks for all accidents and violence $(R R=1.96 ; p<0.001)$, air accidents $(R R=16.46 ; p<0.001)$, and for suicide $(R R=1.67 ; p=0.04 ;$ table 9$)$.

When the three services were considered separately mortality from all accidents and violence was raised significantly compared with national rates for all three (RN: SMR = 132, p < 0.001; Army: SMR $=148, \quad p=0.002 ; \quad R A F: \quad S M R=139$, $\mathrm{p}<0.001$; table 10 ). When the individual categories were considered, mortality from air accidents was significantly increased compared with national rates in all three services (table 10), but much more in the RAF and Army than in the RN. In the RN, however, mortality compared with national rates was also raised for drowning and water transport accidents, and for suicide, whereas in the Army mortality was also raised for motor vehicle traffic accidents and for other injury and poisoning. Of the 25 deaths in this group four may have been occupationally caused; two due to gunshot wounds and two to explosives. After allowing for any possible differences between officers and other ranks, there was significant heterogeneity between the three services for drowning and water transport accidents, air accidents, and suicide ( $p$ values $0.002,<0.001$, and 0.01 ; table 9 ). For drowning and water transport accidents and for suicide mortality was similar in the Army and the RAF and raised in the RN; for air accidents mortality was higher in the RAF and lower in the RN than that in the Army.

\section{Discussion}

From our results it is evident that men who served abroad in the armed forces in the 1950s and 1960s and had at least five years total service have subsequently experienced a lower mortality from all causes, from all neoplasms, and from all other non-violent causes of death than the male population of the country as a whole over the same period. This, moreover, was true with or without allowance for social class differences and, for all causes of death and for all nonviolent causes other than neoplasms, applied to both officers and other ranks. For neoplasms mortality was lower than that experienced by the male population as a whole among both officers and other ranks, but the individual deficits for other ranks before and for officers after adjusting for social class did not quite reach statistical significance.

These findings differ from those reported in the Registrar-General's decennial supplements on occupational mortality, which gave SMRs of between 123 and 165 for men in the armed forces for each of four periods between 1950 and $1983 . .^{1-4}$ The Registrar-General recognises, however, that his SMRs were likely to be biased upwards for the reasons referred to in our introduction and they provide no grounds for thinking that the low mortality recorded in our study has not been typical of men in the forces, except in so far as the men studied may have undergone some further selection to pass them fit for service abroad "in tropical or desert areas." For three categories (all causes, all neoplasms, and all other non-violent causes of death) the SMRs tended to increase with the passage of time after entry to the study, as the effect of selection for good health wore off; but even 15 and more years after entry and at least 20 years after the start of service, the SMRs for both officers and other ranks were still below 100 , although very close to this value in the case of neoplasms (officers 97 and other ranks 93), as is commonly observed in studies of "healthy workers."

The low overall mortality hides, however, the evidence of a few special hazards. The RAF, not surprisingly, had a high mortality from air accidents - extremely high in the case of officers - and the RN had a high mortality from "drowning and water accidents," many of which presumably occurred at sea. Two other findings pointed to specific hazards in the $\mathrm{RN}$, neither of which was unexpected; a small absolute excess of deaths from mesothelioma and a larger absolute, but smaller relative, excess of deaths from cancers and other diseases associated with the consumption of alcohol. This group may be regarded as including suicide, which could account for the excess mortality from this cause in the RN. 
The excess for mesothelioma affected both officers and other ranks. We have no direct evidence that it was due to exposure to asbestos in ships, but it is notable that the deaths with mention of mesothelioma all occurred long enough after enlistment to allow for a typical latent period of more than 15 years (at times of 27, 30, 34, 35, 40, 41, and 41 years after enlistment). The second finding, a high mortality from alcohol related diseases, has been recorded for the $\mathrm{RN}$ in other studies ${ }^{11}$ and has been attributed to the traditional daily ration of rum. As well as the availability of duty free alcohol during service abroad that is common to all three services, the $\mathrm{RN}$ issued one eighth of a pint of $95.5 \%$ proof Jamaica rum to all ratings aged over 20 years until 1970, when this was replaced by a scheme whereby, if a rating is on board ship which is on passage and is not on duty, he is allowed two free cans of beer.

National rates for cirrhosis do not show any strong social class trend, apart from an increase in social class II, in which publicans and innkeepers are included, and also in social class V. SMRs for alcohol related neoplasms such as cancers of the oesophagus and larynx show a strong social class gradient, with low rates in social class $I$, rates about equal to those of the nation as a whole for social class III, and high rates in social class $V$; cancers of the mouth, tongue and pharynx and of the liver show no strong social class gradient except for an increase in social class $\mathrm{V}$. Thus our findings are not accounted for by typical social class patterns.

To investigate the relation between mortality from neoplasms or other diseases related to alcohol and the time that a man had been enlisted in the services, while making due allowance for any selection effect at the time of entry to the study and any differences between officers and other ranks, observed and expected deaths from these two groups of causes were tabulated simultaneously by duration of enlistment $(5-9,10-14,15-19$, and $\geqslant 20$ years $)$, time since entry to the study $(0-4,5-9,10-14,15-20$, and $\geqslant 20$ years) and rank (officers and other ranks). Poisson regres- sion models $^{8}$ were then used to examine the trend in the ratio of observed to expected deaths with increasing duration of enlistment after allowing for an effect of rank and time since entry to the study. For cancers associated with alcohol, mortality tended to increase by $15 \%$ for each additional five years spent in the services, but the trend was not statistically significant $\left(\chi_{1}^{2}=0.73 ; p=0 \cdot 39\right)$. For other diseases related to alcohol, however, the increase in mortality with increasing duration of enlistment was significant $\left(\chi_{1}{ }^{2}=5.15 ; p=0.02\right)$. This corresponded to an increase of $46 \%$ in the mortality associated with each additional five years of enlistment. Table 11 summarises the data for both neoplasms and other diseases.

The only other evidence of increased mortality was for cancer of the prostate, which was observed in both officers and other ranks and was statistically significant for all ranks combined (SMR 156, $p=0.03)$. Cancer of the prostate shows little variation with social class. The excess was observed in both the RN and the RAF (SMR in each case 178) and was statistically significant for the RAF, although it was absent from the Army (SMR 36 based on one death). A raised relative SMR (the ratio of the SMR to the SMR for all causes) for prostate cancer has been observed previously among members of the United Kingdom armed forces in cancer mortality data from the decennial supplements, ${ }^{12}$ and high mortality from prostatic cancer has also been observed among members of the armed forces in the United States and the Netherlands, ${ }^{13}$ but the cause for these increases remains unknown.

More remarkable than these few excesses are the deficiencies in the mortality from diseases associated with smoking other than those also associated with alcohol. The SMRs were less than 100 for both officers and other ranks, for all three services individually, and for the two groups of cancers and other tobacco related diseases. For tobacco related diseases other than cancer these deficits were all highly significant, whereas for the cancers the

Table 11 SMRs and ratios of observed (Obs) to expected (Exp) deaths from cancers and other diseases associated with alcohol in the $R N$ by time since entry to the study and duration of service

\begin{tabular}{|c|c|c|c|c|c|c|}
\hline \multirow[b]{3}{*}{ Cause of death } & \multirow{3}{*}{$\begin{array}{l}\text { Duration of } \\
\text { service }(y)\end{array}$} & & \multicolumn{2}{|l|}{ Officers } & \multicolumn{2}{|c|}{ Other ranks } \\
\hline & & & \multicolumn{2}{|c|}{ Time since entry to study (y) } & \multicolumn{2}{|c|}{ Time since entry to study (y) } \\
\hline & & & $<15$ & $\geqslant 15$ & $<15$ & $\geqslant 15$ \\
\hline $\begin{array}{l}\text { Cancers associated with alcohol } \\
\text { (mouth, etc, oesophagus, larynx, } \\
\text { liver) }\end{array}$ & $\begin{array}{l}5-14 \\
\geqslant 15\end{array}$ & $\begin{array}{l}\text { SMR } \\
\text { Obs/Exp } \\
\text { SMR } \\
\text { Obs/Exp }\end{array}$ & $\begin{array}{l}0 \\
0 / 0.03 \\
0 \\
0 / 0.66\end{array}$ & $\begin{array}{l}0 \\
0 / 0 \cdot 09 \\
331 \\
8 / 2 \cdot 42\end{array}$ & $\begin{array}{l}208 \\
2 / 0 \cdot 96 \\
227 \\
4 / 1 \cdot 76\end{array}$ & $\begin{array}{l}113 \\
6 / 5 \cdot 29 \\
184 \\
14 / 7 \cdot 61\end{array}$ \\
\hline $\begin{array}{l}\text { Other diseases related to alcohol } \\
\text { (cirrhosis of liver, alcoholism, and } \\
\text { alcoholic psychosis) }\end{array}$ & $\begin{array}{l}5-14 \\
\geqslant 15\end{array}$ & $\begin{array}{l}\text { SMR } \\
\text { Obs/Exp } \\
\text { SMR } \\
\text { Obs/Exp }\end{array}$ & $\begin{array}{l}0 \\
0 / 0 \cdot 02 \\
298 \\
1 / 0 \cdot 34\end{array}$ & $\begin{array}{l}0 \\
0 / 0 \cdot 05 \\
103 \\
1 / 0.97\end{array}$ & $\begin{array}{l}243 \\
2 / 0 \cdot 82 \\
0 \\
0 / 1 \cdot 09\end{array}$ & $\begin{array}{l}115 \\
5 / 4 \cdot 34 \\
454 \\
17 / 3 \cdot 75\end{array}$ \\
\hline
\end{tabular}


deficits reached statistical significance for all officers combined, for the Army, and for the RAF. Deficiencies were not observed for all the individual diseases within these two groups (particularly not for cancers of the kidney and pancreas nor for aneurysms of the aorta) but the numbers of deaths attributable to these diseases were relatively few and in no case was the number statistically incompatible with a moderate deficiency. In some cases the reduced mortality may have been partly due to some specific feature of service abroad in the armed forces, such as above average physical activity in the case of coronary heart disease and the effect of physical selection in the case of chronic obstructive lung disease. It is difficult, however, to escape the conclusion that, despite the availability of very cheap cigarettes for the services during the war, of duty free cigarettes during service abroad since then and evidence of high levels of cigarette smoking among British soldiers generally, ${ }^{14}{ }^{15}$ the members of the armed forces that we have studied smoked less than the national average; otherwise they could hardly have had such a low mortality from cancer of the lung (230 deaths, SMR 73, $\mathrm{p}<0.001)$.

The study on which this paper is based was commissioned by and carried out for the Ministry of Defence. We are most grateful to the Ministry staff who assisted with the data collection, and to the staffs of the National Health Service Central Registers and the Records Branch of the Department of Social Security for their work in providing follow up information. We also thank Rosanne Richardson, Lindsey Cutler, and Valerie Weare for help in preparing the manuscript.
1 Registrar General. Decennial supplement, England and Wales, 1951, Occupational mortality. Part II, Vol 2, tables. London: HMSO, 1958.

2 Registrar General. Decennial supplement, England and Wales, 1961, Occupational mortality. Tables. London: HMSO, 1971.

3 Office of Population Censuses and Surveys. Occupational mortality 1970-72. London: HMSO, 1978. (DS No 1.)

4 Office of Population Censuses and Surveys. Occupational mortality 1979-80, 1982-3. London: HMSO, 1986. (DS No 6.)

5 Darby SC, Kendall GM, Fell TP, et al. A summary of mortality and incidence of cancer in men from the United Kingdom who participated in the United Kingdom's atmospheric nuclear weapon tests and experimental programmes. $\mathrm{Br}$ Med $J$ 1988;296:332-8.

6 Darby SC, Kendall GM, Fell TP, et al. Mortality and Cancer Incidence in UK Participants in UK Atmospheric Nuclear Weapon Tests and Experimental Programmes. London: Her Majesty's Stationery Office, 1988. (NRPB-R214.)

7 Darby SC, O'Hagan JA, Kendall GM, Doll R, Fell TP, Muirhead CR. Completeness of follow-up in a cohort study of mortality using the United Kingdom National Health Service Central Registers and records held by the Department of Social Security. J Epidemiol Community Health (in press).

8 Payne $\mathrm{CD}$, ed. The generalised linear interactive modelling system. Release 3.77. Oxford: Numerical Algorithms Group Ltd, 1986.

9 Fox AJ, Collier PF. Low mortality rates in industrial cohort studies due to selection for work and survival in the industry. British Journal of Preventive and Social Medicine 1976;30: 225-30.

10 IARC. International Agency for Research on Cancer monographs on the evaluation of carcinogenic risks to humans. Vol 44. Alcohol drinking. Lyon: IARC, 1988.

11 Dunbar-Miller RA. Alcohol and the fighting man - an historical review. J R Army Med Corps 1984;130:117-21.

12 Logan WPD. Cancer mortality by occupation and social class 1851-1971. London: HMSO and Lyon: IARC, 1982. (IARC sci publ No 36 and studies on medical and population subjects No 44.)

13 Mandel JS, Schuman LM. Epidemiology of Cancer of the prostate. Reviews in Cancer Epidemiology 1980;1:1-73.

14 Crowdy JP, Sowden RR. Cigarette smoking and respiratory illhealth in the British Army. Lancet 1975;i:1232-4.

15 Richards HJA, Crowdy JP. Smoking habits of young soldiers. British Journal of Preventive and Social Medicine 1961;15: 84-8.

Accepted 23 July 1990 